\title{
Yaupon Holly Culture and Pest Management for Tea Production and Ornamental Use ${ }^{1}$
}

\author{
Matthew A. Borden, Mark A. Wilhelm, and Adam G. Dale ${ }^{2}$
}

Yaupon holly, Ilex vomitoria Aiton (Figure 1), is an evergreen woody plant native to the southeastern United States. The species is widely used as a landscape ornamental plant because it tolerates a wide range of soil and environmental conditions, is available in various forms, and is well-suited for Florida-Friendly Landscaping ${ }^{\text {mu }}$ (https://edis.ifas.ufl. edu/topic_ffl) because it requires few inputs and attracts wildlife, especially native birds. Recently, there has been a resurgence of interest in cultivating the plant for the caffeinated beverages that can be made from its leaves. Although commonly called yaupon tea, it should be noted that the word "tea" properly refers to beverages produced from the tea plant, Camellia sinensis. Infusions made with all other plants, such as herbs and yaupon holly, are considered tisanes. For commercial growers and homeowners to effectively grow and maintain yaupon holly for tea production or as an ornamental plant, it is important to be familiar with its pest susceptibility and management recommendations.

\section{Biology and Distribution}

Yaupon holly is a hardy, evergreen shrub or small tree in the family Aquifoliaceae. This species naturally occurs across the southeastern coastal plain of the United States from Texas to Virginia. In Florida, its range extends south to around Highlands and Sarasota counties or Lake Okeechobee (USDA-NRCS 2019). In cultivation, yaupon holly is now grown in other regions of the United States, including the West Coast.
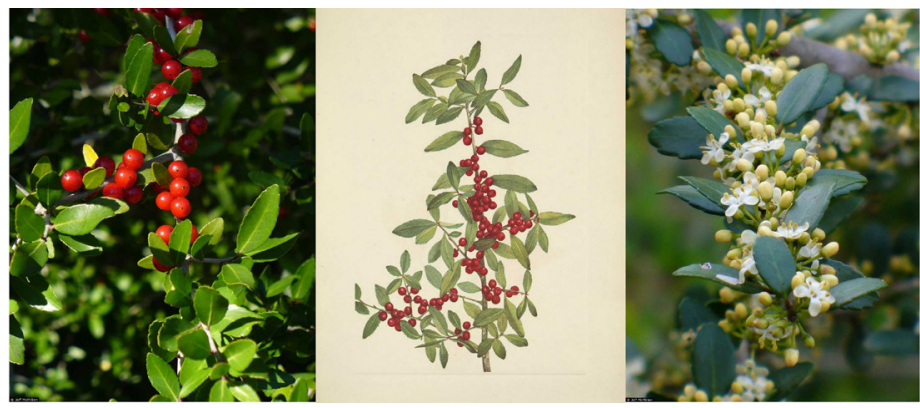

Figure 1. Yaupon holly, llex vomitoria.

Credits: Jeff McMillian, hosted by the USDA-NRCS PLANTS Database. Illustration credit: Mary Vaux Walcott, North American Wild Flowers, vol. 3 (1925)

Yaupon holly typically blooms for several weeks between March and May with small white flowers, sometimes tinged with pink. As with all Ilex species, yaupon holly is dioecious, meaning individual plants are either male or female. Male flowers are more abundant and produce pollen, while female flowers produce nectar and, if pollinated, produce bright red berries that remain on the plants until the following year. Yaupon holly is unusual among North American plants because it produces caffeine in its twigs and foliage (Immel 2000; Edwards and Bennett 2005).

Yaupon holly is naturally found growing in sandy, welldrained soils in a variety of habitats, including hammocks, pine flatwoods, and sandhills. The plant is also tolerant of temporarily wetter soils and salt spray and can be found on sand dunes, in maritime hammocks, and along the borders of coastal marshes (Immel 2000; Shadow 2011). Because of

1. This document is ENY-2054, one of a series of the Entomology and Nematology Department, UF/IFAS Extension. Original publication date December 2020. Visit the EDIS website at https://edis.ifas.ufl.edu for the currently supported version of this publication.

2. Matthew A. Borden, graduate research assistant; Mark A. Wilhelm undergraduate student; and Adam G. Dale, assistant professor; Entomology and Nematology Department, UF/IFAS Extension, Gainesville, FL 32611.

The Institute of Food and Agricultural Sciences (IFAS) is an Equal Opportunity Institution authorized to provide research, educational information and other services

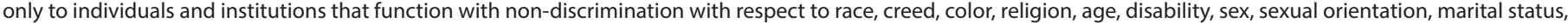

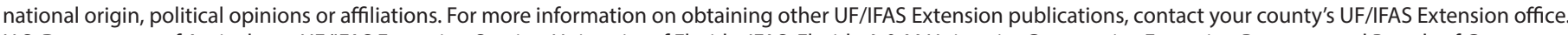
U.S. Department of Agriculture, UF/IFAS Extension Service, University of Florida, IFAS, Florida A \& M University Cooperative Extension Program, and Boards of County Commissioners Cooperating. Nick T. Place, dean for UF/IFAS Extension. 
these broad adaptations, yaupon holly has become popular as an ornamental plant and is well-suited to withstand stressful conditions common in urban areas and coastal landscapes.

\section{Landscape Characteristics and Ecosystem Services}

Yaupon holly is considered one of the hardiest holly species grown in the southeastern United States. Yaupon transplants readily during the cooler seasons, and once the plants are established, supplemental irrigation is not required to maintain a good growth rate, making them suitable for xeric landscaping (Shadow 2011; Scheiber et al. 2008). Established plants are highly drought tolerant and perform well even in hot, exposed locations (Figure 2). Yaupon holly can be grown as a tree, large or small shrub, or hedge (Immel and Anderson 2009). A variety of cultivars and forms are available, such as 'Nana', a female dwarf form; 'Schilling's Dwarf', an even smaller male form; 'Pendula, a weeping form; 'Jewel', a heavily fruiting selection; 'Scarlet's Peak', a female columnar form, and 'Aurea', which has yellow berries (Galle 1997; Gilman and Watson 2018).

Yaupon holly berries are a significant resource for wildlife, including songbirds, gamebirds, and small mammals such as raccoons and squirrels. Notably, at least 28 species of birds reportedly feed on the fruit, a valuable food source during the winter when other resources may be scarce (Martin and Mott 1997). Therefore, homeowners wanting to attract wildlife with yaupon holly should consider berryproducing cultivars, not male plants such as 'Schilling's Dwarf' or the rarely fruiting female 'Nana'. The evergreen

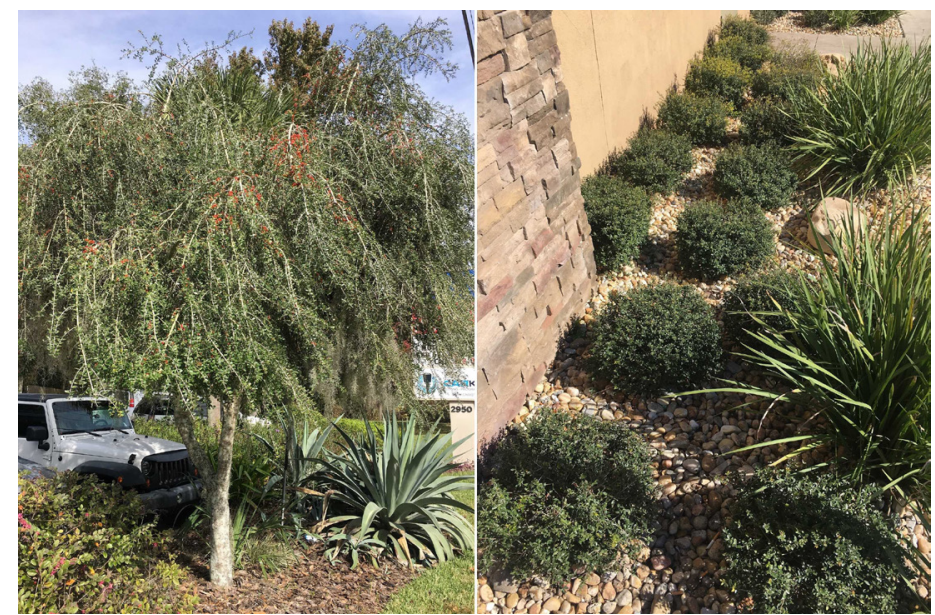

Figure 2. Weeping (left) and dwarf (right) forms of yaupon holly, llex vomitoria, used in urban landscapes.

Credits: Matthew Borden, UF/IFAS leaves not only provide year-round color in a landscape, but also shelter animals in the winter months as the thicket-like growth of larger shrubs and trees serves as valuable nesting and roosting habitat (Martin and Mott 1997). Yaupon holly is also tolerant of white-tailed deer, which occasionally feed on the foliage (Immel 2000).

For more information on yaupon holly identification and landscape use, see UF/IFAS Extension factsheet ENH470, Ilex vomitoria: Yaupon Holly (https://edis.ifas.ufl.edu/ st311).

\section{History and Use of Yaupon Holly}

For centuries, yaupon holly was consumed by many groups of Native Americans, who brewed it into a caffeinated beverage similar to tea or coffee and likely transplanted it for cultivation within southeastern North America (Hammett 1992). The beverage, which became known as "black drink," was primarily drunk by men to maintain ritual purity, although it was also used regularly as a social or medicinal drink. Some early European reports describe it being used to induce vomiting in rituals, hence the specific epithet, vomitoria. However, tea made from yaupon holly is not known to have any emetic or toxic properties. Thus, it is likely that these reports stemmed from either mixing yaupon tea with other substances or simply consuming the drink in such high quantities as to bring about vomiting (Hudson 1979; Palumbo et al. 2009). Indigenous peoples reportedly prepared the tea by sun-drying the leaves and roasting them in an oven or pan. Other preparations may have used fresh or fermented leaves, possibly including a fermented alcoholic beverage (Hale 1891).

Spanish colonists in Florida quickly adopted use of the beverage for medicinal and then casual consumption, followed by other European settlers in the Carolinas. The drink gradually declined in use, likely in conjunction with the rising popularity of tea (Camellia sinensis (L.) Kuntze) and coffee (Coffea spp. L.), but again became popular during the American Civil War as a tea or coffee substitute in the South. However, association with the rural poor damaged the drink's reputation and it soon fell out of favor (Hudson 1979).

Interest in yaupon tea has recently increased as a locally grown and sustainable alternative to coffee and tea in the southeastern United States. (Palumbo et al. 2009). In Florida, commercial yaupon producers have experienced widespread interest and collaboration requests from the health beverage industry, the alcoholic beverage industry, and growers seeking to diversify their crops. There is even 
a re-established market in overseas exports. Commercial producers now cultivate yaupon holly or harvest it sustainably from wild stands and package it as a loose-leaf product or in tea bags for convenient steeping (Figure 4).

To prepare an infusion of yaupon, leaves and stems from any part of the plant are pruned and lightly washed, discarding any berries and debris. Stems may be removed if desired, but do not negatively affect flavor. After dehydrating leaves and stems by air or sun drying, the material can be stored whole or crushed and blended into smaller pieces prior to steeping in hot water. Steeping the dried, green material produces a caffeinated beverage reminiscent of green tea, with bright, grassy flavors. Alternatively, the leaves may be lightly roasted by tossing in a hot dry pan to produce an earthier beverage, with hints of malt and toasted coffee.

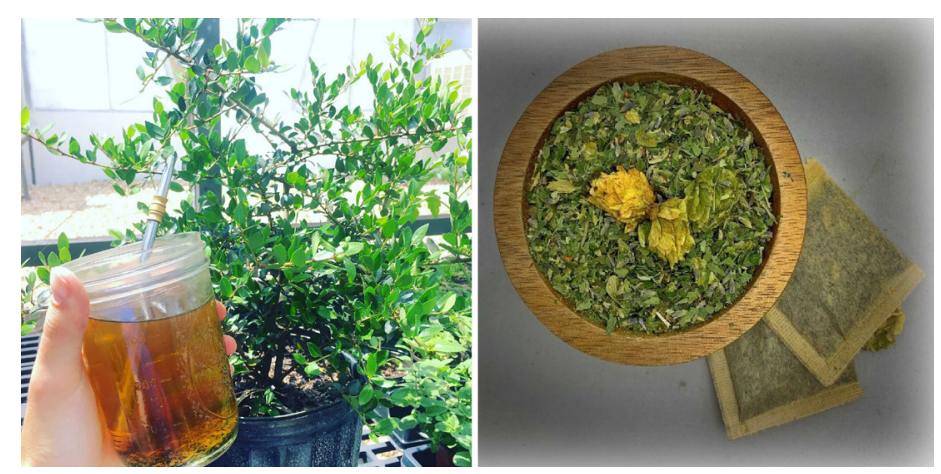

Figure 4. Home-brewed tisane made from dried and lightly roasted leaves (left), and locally produced and bagged yaupon tea, llex vomitoria (right).

Credits: Matthew Borden, UF/IFAS; and Bryon White, Yaupon Brothers American Tea Co., respectively

\section{Yaupon Holly Management Cultural Management}

Yaupon holly can be grown from seed but is typically propagated by cuttings (https://edis.ifas.ufl.edu/ep536) to maintain desired cultivar traits, such as form and sex. Transplanting should be done in the cooler seasons so that plants are well-established before they are exposed to summer heat and water stress. New plantings may benefit from supplemental watering and light application of balanced fertilizer to hasten establishment (Shadow 2011), but thereafter fertilizers should be used prudently and only if needed. Excessive fertilization, particularly with nitrogen, is not recommended. Not only is nitrogen an important pollutant in urban landscapes (https://edis.ifas.ufl.edu/ ss681) but fertilizing too much can make pest management more difficult. The tender, nutrient-rich flushes of new growth caused by excess fertilization may benefit pest species that prefer to feed there, such as aphids (Herms
2002). Overwatering should be avoided because yaupon holly generally does not need supplemental irrigation once established in the landscape. When drought stressed, yaupon leaves lose their glossy appearance, feel stiff, and may turn brown and fall from the plant.

Promoting natural enemies and biological control of plant pests (https://edis.ifas.ufl.edu/in120) is an important part of integrated pest management (IPM) and sustainable plant maintenance. Yaupon holly is a good candidate for encouraging biological control because it has no major pests, which allows for low levels of plant-feeding insects that support predator and parasite (natural enemy) populations, helping to prevent more serious pest outbreaks in the landscape. Moreover, pesticides labelled for tea plants are generally of minimal risk to natural enemies when used correctly. Natural enemies, such as parasitoid wasps, lady beetles, and lacewings are abundant in the Southeast and can be attracted to the landscape with diverse habitats and flowering plants (Landis et al. 2000). However, because many natural enemies specialize on specific insects, any plans to purchase and use biological control agents from commercial sources should be well-researched beforehand (https://edis.ifas.ufl.edu/in849).

\section{Chemical Management}

Because yaupon holly can be grown either as an ornamental plant or for consumption of the foliage as tea, pesticide use and selection depends on the intended use of the plant. Where yaupon holly is grown solely for aesthetic value as an ornamental, products labeled for ornamentals and landscape use are appropriate, although rarely necessary. Where yaupon holly is grown for consumption, only products approved for use on tea plants are acceptable. These are primarily naturally derived and organic pesticides, such as neem oil, azadirachtin (a neem derivative), pyrethrins, insecticidal essential oils, horticultural oil, and Beauveria bassiana (an entomopathogenic fungus). For more information on these kinds of products and how to safely apply them, see Natural Products for Managing Landscape and Garden Pests in Florida (http://edis.ifas.ufl. edu/in197). Luckily, current production methods suggest that yaupon holly can be grown for consumption without the use of pesticides.

\section{Associated Insect Herbivores Yaupon Psyllid}

The yaupon psyllid, Gyropsylla ilecis (Ashmead) (Hemiptera: Aphalaridae), is a tiny insect whose only known host is yaupon holly (Figure 5). Adult female yaupon psyllids lay eggs on new shoots and buds around February or March 
each year. After the eggs hatch, the nymphs feed on young, newly emerging leaves, causing them to deform and fold around the nymphs into protective gall-like structures. The nymphs remain inside the galls until the following spring, when they complete their development and molt into adults. Gyropsylla ilecis is not known to cause serious damage to yaupon holly and is primarily an aesthetic concern for landscape use (Mead 1983). Interestingly, dwarf cultivars of yaupon holly, such as 'Nana', seem to be unaffected by this insect. The effects of this psyllid on commercial yaupon holly operations are unknown. More information about this insect can be found at, http://entnemdept.ufl. edu/creatures/ORN/SHRUBS/yaupon_psyllid.html.

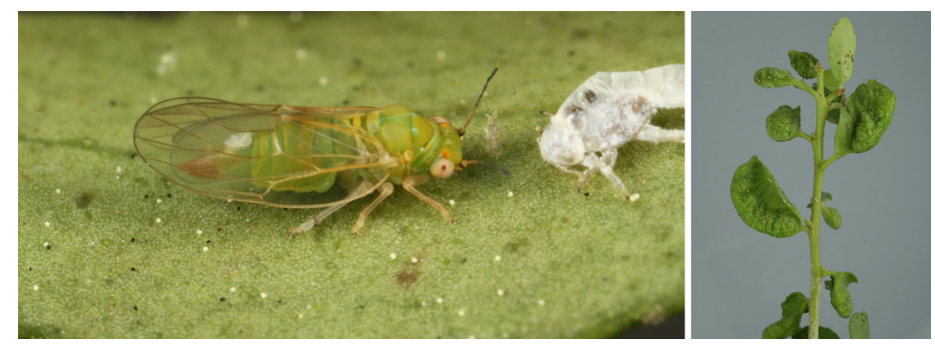

Figure 5. Adult yaupon psyllid, Gyropsylla ilecis, on a yaupon leaf (left) and associated galls on yaupon holly, llex vomitoria (right).

Credits: Lyle Buss, UF/IFAS

\section{Leafminer Complex}

The leafminer fly, Phytomyza vomitoriae Kulp (Diptera: Agromyzidae) is a poorly studied insect known to feed on yaupon holly. The adult, a small dark brown fly, lays an egg inside the leaves of yaupon holly. The tiny larva hatches and begins feeding inside the leaf, creating a "mine" between the leaf's upper and lower surfaces (Figure 6). This mine expands in length and width as the larva matures until exiting the leaf to pupate and later emerge as an adult. Agromyzids generally take between one week and a few months to complete the larval stage. Phytomyza vomitoriae has one generation per year, and the mines are characteristically straight at first before changing direction. This species is part of the Phytomyza ilicis species group, which is comprised of about 12 Phytomyza spp. that feed on various hollies in North America (Lonsdale and Scheffer 2011; Spencer and Steyskal 1986). Fortunately, Phytomyza leafminers are only a minor aesthetic concern for ornamental yaupon plants and likely present little risk for tea production.

\section{Aphids}

Aphids in the genus Toxoptera Koch (Hemiptera: Aphididae) have been observed feeding on new growth of yaupon holly (Figure 7) (Blackman and Eastop 2018). As with many aphid species, they are frequently attended by ants, which feed on their honeydew excretions and protect them from predators (Jiggins et al. 1993). Only the species Toxoptera aurantii (Boyer de Fonscolombe) is currently known to feed on plants in the family Aquifoliaceae, which includes the hollies. This aphid originates from southeastern Asia and is a common agricultural pest (Qiao et al. 2008). Little else is known about the relationship between this aphid and yaupon holly, although it does not appear to cause significant damage.

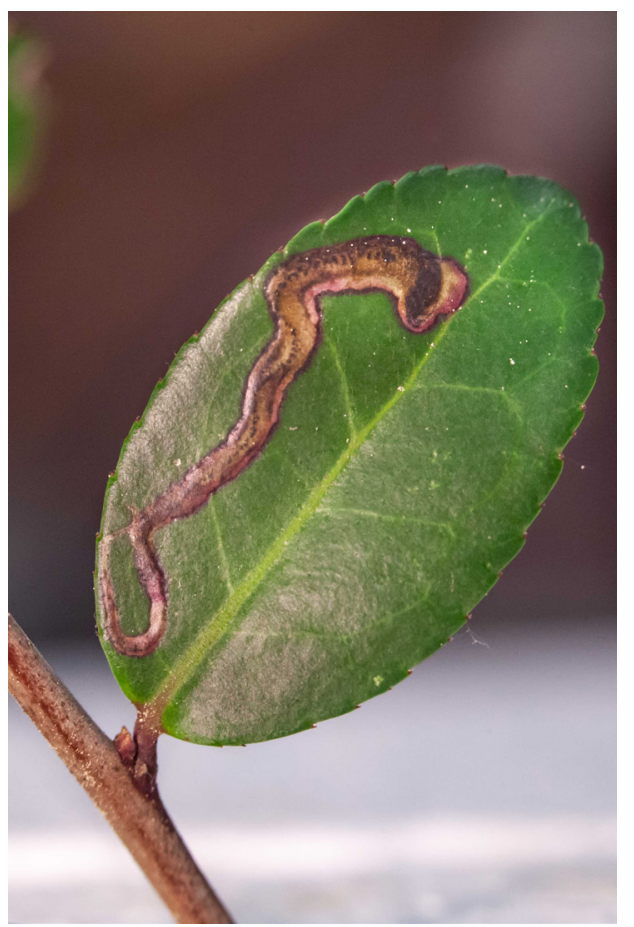

Figure 6. A leaf mine from an Agromyzid leafminer on yaupon holly, Ilex vomitoria.

Credits: Matthew Borden, UF/IFAS

\section{Caterpillars}

The holly looper, Ilexia (=Thysanopyga) intractata (Walker) (Lepidoptera: Geometridae) (Figure 8), is the caterpillar of the black-dotted ruddy moth, native to the southeastern United States. As they feed, these caterpillars cause notches in the leaf margins of several evergreen holly species, including American holly (Ilex opaca) and yaupon holly. The caterpillars are green, about $2 \mathrm{~cm}$ long, and pupate in the soil beneath their host plants.

Caterpillars of the species Episemasia solitaria (Walker) (Lepidoptera: Geometridae) (Figure 9a) also feed on the same hollies, likely causing similar feeding patterns on the foliage (Ferguson 2009). Yaupon holly is also a host plant for caterpillars of the pawpaw sphinx moth, Dolba hyloeus (Drury) (Lepidoptera: Sphingidae) (Figure 9b) (Hodges 


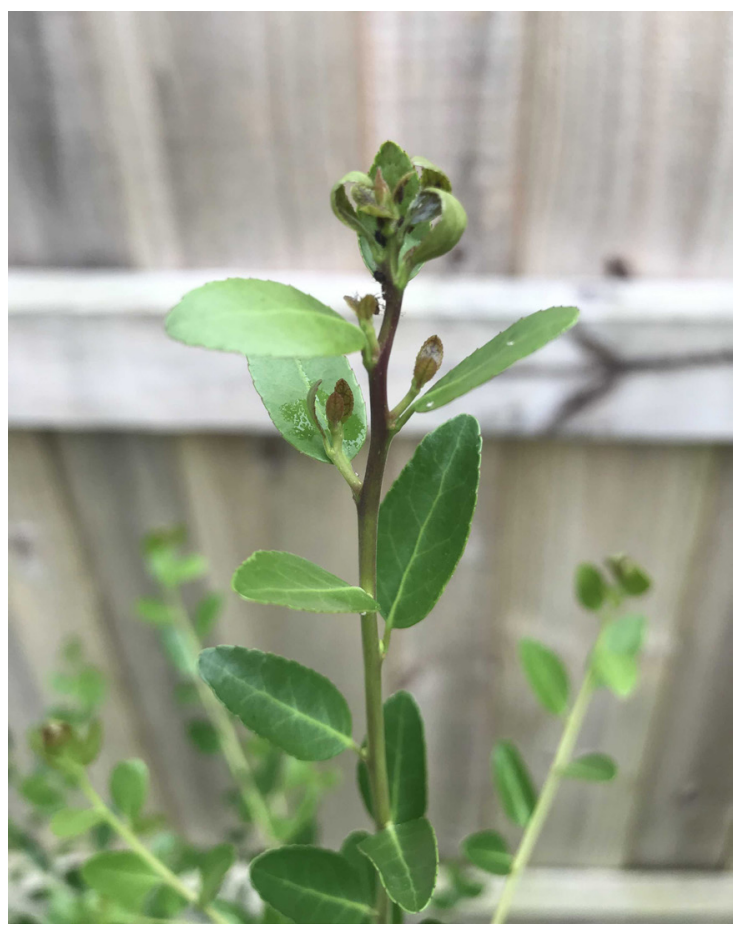

Figure 7. Yaupon holly, llex vomitoria, showing distorted growth of new leaves due to aphid feeding.

Credits: Bryon White

1971). This caterpillar, which occurs in bright green or brown forms, feeds from the tip of a twig backwards toward the branch, often eating entire leaves rather than causing notching; however, the twig generally produces new leaves again the following year (George Smiley, personal correspondence). Caterpillars on yaupon holly are relatively uncommon and are not known to cause significant damage; therefore, tolerating their feeding or manual removal from the plant is likely the best control option if necessary.
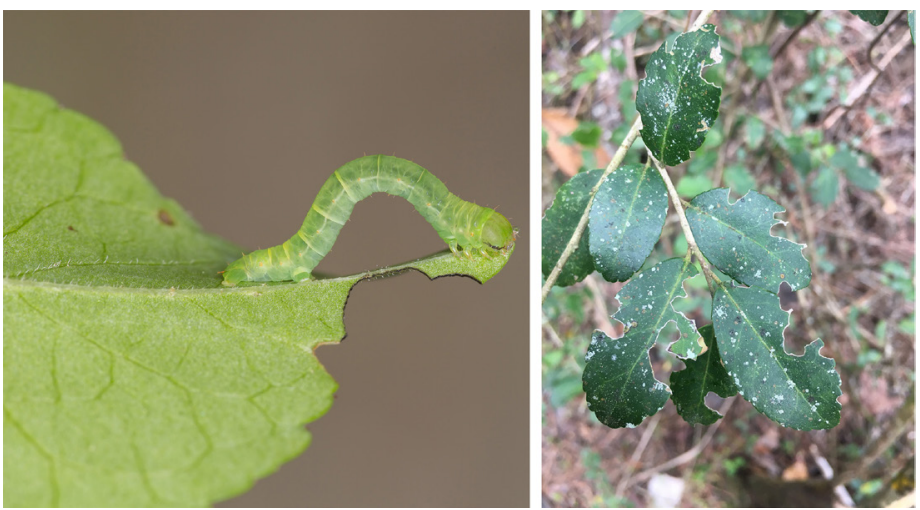

Figure 8. Holly looper (llexia intractata) caterpillar (left), and caterpillar feeding damage on yaupon holly (right).

Credits: George Smiley, UF/IFAS and Matthew Borden, UF/IFAS, respectively

\section{Scale Insects}

Several armored and soft scale insect (https://edis.ifas.ufl. edu/mg005) species are known to feed on yaupon holly (Figure 10). Armored scale insect species (Hemiptera: Diaspididae) known to feed on yaupon holly are (Dekle 1965):

- Acutaspis perseae (Comstock), red bay scale

- Duplaspidiotus claviger (Cockerell.), camellia mining scale

- Fiorinia theae Green, tea scale

- Hemiberlesia lataniae (Signoret), latania scale

- Howardia biclavis (Comstock), mining scale

- Melanapsis smilacis (Comstock), smilax scale

- Pseudaonidia duplex (Cockerell), camphor scale

- Pseudoparlatoria parlatorioides (Comstock), false parlatoria scale

- Quadraspidiotus forbesi (Johnson), Forbes scale

Known soft scale insect pests (Hemiptera: Coccidae) of yaupon holly include (Hamon and Williams 1984):

- Ceroplastes ceriferus (Fabricius), Indian wax scale

- Ceroplastes cirripediformis Comstock, barnacle scale

- Ceroplastes floridensis Comstock, Florida wax scale
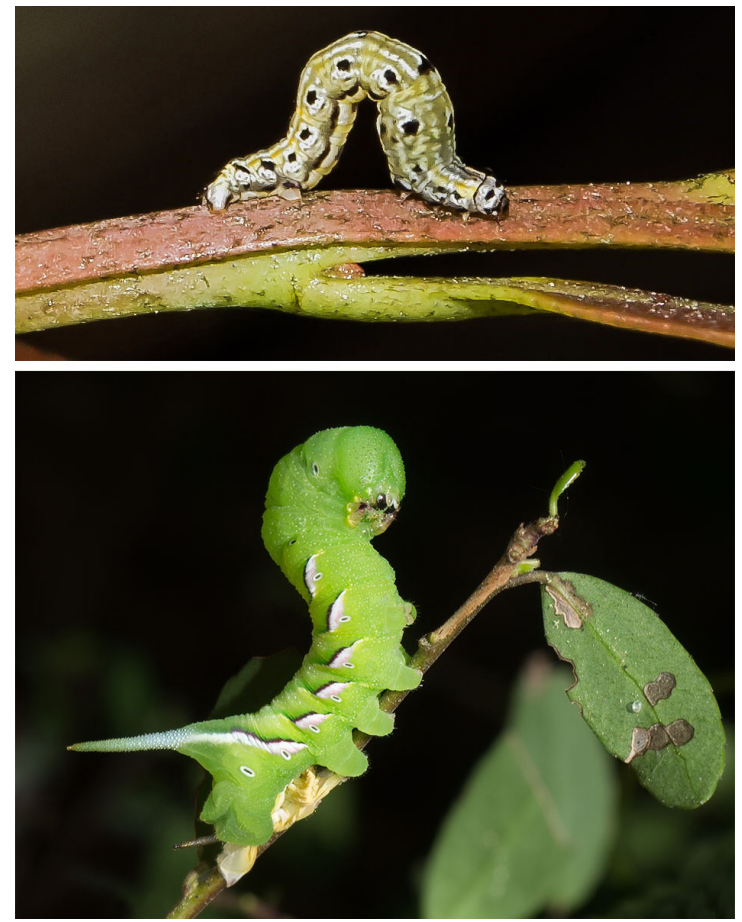

Figure 9. Two other caterpillars known to feed on yaupon holly, llex vomitoria, are Episemasia solitaria (left) and Dolba hyloeus with signs of feeding (right).

Credits: Karen Chiasson, bugguide.net 
- Coccus viridis (Green), green scale

- Eucalymnatus tessellatus (Signoret), tessellated scale

- Kilifia acuminata (Signoret), acuminate scale

- Protopulvinaria pyriformis (Cockerell), pyriform scale

- Pulvinaria innumerabilis (Rathvon), cottony maple scale

- Saissetia oleae (Oliver), black scale

Observations suggest that armored scales generally inflict minimal damage to yaupon holly, including a recent UF/ IFAS study demonstrating low susceptibility to tea scale, one of the most common pests of hollies, particularly 'Dwarf Burford' (Borden and Dale 2020). Aside from host records, the effects of soft scale species on yaupon holly are poorly studied. Interestingly, one study found yaupon holly was also resistant to Florida wax scale, Ceroplastes floridensis, compared with other hollies (Hodges et al. 2001).

\section{Other Insects}

Flatid planthoppers (Hemiptera: Flatidae) are common plant-feeding insects that may be found on shrubs, trees, and vines. For example, the citrus flatid planthopper, Metcalfa pruinosa (Say) (https://edis.ifas.ufl.edu/in605), is common on a wide variety of ornamental plants in the eastern United States. Adults are distinctly wedge-shaped and 5.5 to $8 \mathrm{~mm}$ long. Nymphs are often covered in waxy, cottony, wool-like filaments (called flocculant) that make this planthopper very conspicuous on plants. Homeowners are often concerned about the presence of these insects and mistake them for more serious pests, such as mealybugs or cottony-cushion scale (https://edis.ifas.ufl.edu/in161). While the planthoppers do feed on plant sap, damage is usually negligible, making this pest only a minor aesthetic issue (Mead 2014).

Interestingly, yaupon holly has been found generally resistant to the twolined spittlebug, Prosapia bicincta (Say), a related pest of American and Dahoon hollies, (Braman and Ruterj 1995).

\section{Summary}

Yaupon holly is well-established in Florida as a landscape ornamental plant. More recently, it is re-emerging as an edible landscape plant for home tea production as well as commercial production of caffeinated beverages. Yaupon holly has no severe disease issues and very few pests likely to cause significant damage. However, plant and insect interactions may change under different growing methods, and new observations of insects and pest damage associated with the crop are worth noting and welcomed. Please contact the authors to provide more information.

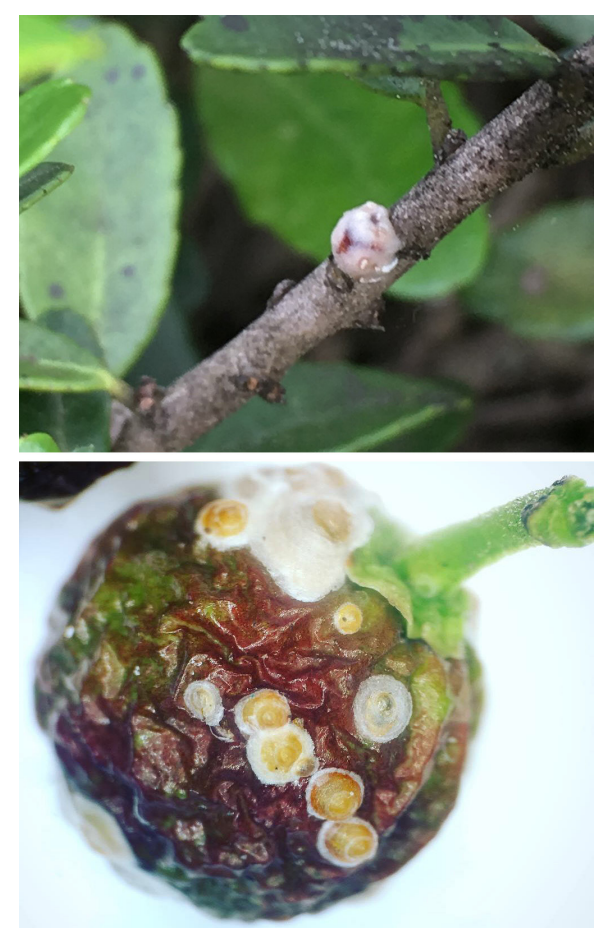

Figure 10. Scale insects, Ceroplastes sp. (left) and Hemiberlesia lataniae (right), on yaupon holly, Ilex vomitoria. Credits: Matthew Borden, UF/IFAS
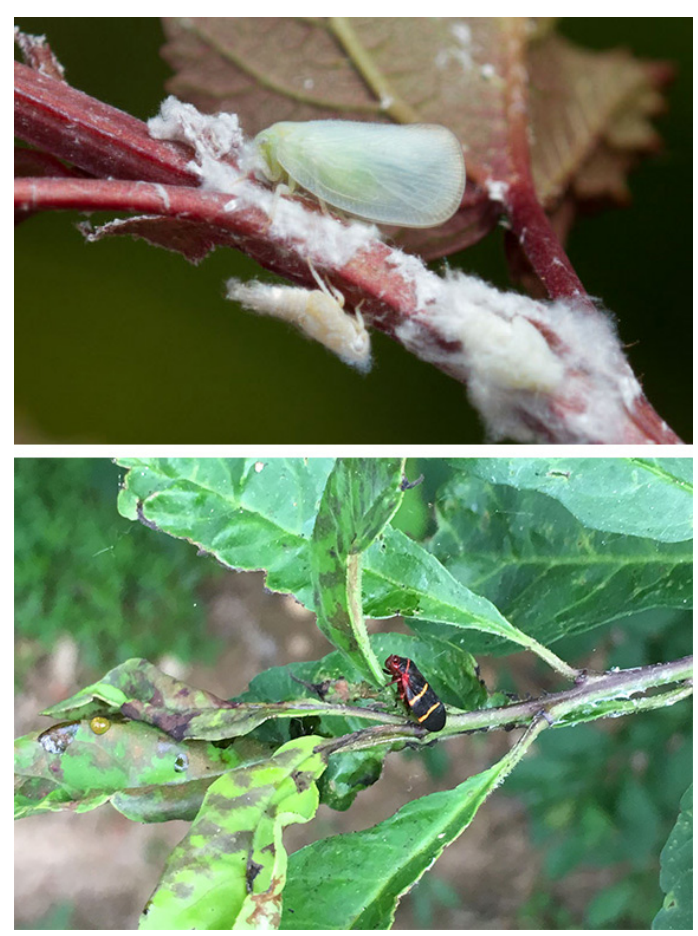

Figure 11. Flatid planthoppers feeding on a shrub stem with abundant waxy flocculant material (left) and twolined spittlebug with feeding damage on a different llex species (right).

Credits: Debbie Roos, North Carolina Cooperative Extension, and Matthew Borden, UF/IFAS 


\section{References}

Blackman, R. L., and V. F. Eastop. 2018. Aphids on the World's Plants: An online identification and information guide. Edited by Braman, K. S., and J. M. Ruterj. 1995. "Preference of Twolined Spittlebug for Ilex Species, Hybrids." Journal of Environmental Horticulture. 15:211-214. http://www.aphidsonworldsplants.info/

Borden, M. A., and A. G. Dale. 2020. "Native and Edible Ornamental Plant Congeners Enhance Ecosystem Services Through Key Pest Avoidance and Multifunctionality in Residential Landscapes." Environmental Entomology 49 (5): 1206-1213.

Dekle, G. W. 1965. Arthropods of Florida and Neighboring Land Areas Vol. 3: Florida armored scale insects. Florida Department of Agriculture and Consumer Services, Division of Plant Industry. https://www.fdacs.gov/ezs3download/download/25108/516024/arthropods-of-florida-vol-3. pdf

Edwards, A. L., and B. C. Bennett. 2005. "Diversity of Methylxanthine Content in Ilex cassine L. and Ilex vomitoria Ait: Assessing Sources of the North American Stimulant Cassina." Economic Botany 59 (3): 275-285.

Ferguson D. C. 2009. A revision of the red-brown caberine geometrids of the southeastern United States (Geometridae: Caberini). Tropical Lepidopteran Research 19 (1): 35-51. https://journals.flvc.org/troplep/article/view/90258

Gilman E. F., D. G. Watson, R. W. Klein, A. K. Koeser, D. R. Hilbert, and D. C. McLean. 2018. Ilex vomitoria: Yaupon Holly. Gainesville: University of Florida Institute of Food and Agricultural Sciences. https://edis.ifas.ufl.edu/st311

Hale, E. M. 1891. "Ilex cassine: The Aboriginal North American Tea." USDA Division of Botany Bulletin 14:1-22.

Hammett, J. E. 1992. “The Shapes of Adaptation: Historical Ecology of Anthropogenic Landscapes in the Southeastern United States." Landscape Ecology. 7:121-135.

Hamon, A. B, and M. L. Williams. 1984. "Arthropods of Florida and Neighboring Land Areas Vol. 11: The Soft Scale Insects of Florida." Florida Department of Agriculture and Consumer Services, Division of Plant Industry. https:// www.fdacs.gov/ezs3download/download/25116/516032/ arthropods-of-florida-vol-11.pdf

Herms D. A. 2002. "Effects of Fertilization on Insect Resistance of Woody Ornamental Plants: Re- Assessing an Entrenched Paradigm." Environmental Entomology. 31:923-33

Hodges G., J. M. Ruter, and S. K. Braman. 2001. "Susceptibility of Ilex species, hybrids and cultivars to Florida wax scale (Ceroplastes floridensis Comstock)." Journal of Environmental Horticulture 19 (1): 32-36. https://doi. org/10.24266/0738-2898-19.1.32

Hodges, R. W. 1971. The Moths of America North of Mexico. Fascicle 21. Sphingoidea. E. W. Classey Limited and R.B.D. Publications Inc., London.

Hudson C. 1979. Black Drink: A Native American Tea. University of Georgia Press, Athens, GA. 175 pp.

Immel D. L. 2000. Plant guide for yaupon (Ilex vomitoria). USDA-Natural Resources Conservation Service, National Plant Data Center, c/o Environmental Horticulture Department, University of California, Davis, California. https:// plants.usda.gov/plantguide/pdf/pg_ilvo.pdf

Jiggins C., M. Majerus, and U. Gough. 1993. Ant defence of colonies of Aphis fabae Scopoli (Hemiptera: Aphididae), against predation by ladybirds. British Journal of Entomology and Natural History, 6 (4): 129-137.

Johnson W. T., and H. H. Lyon. 1991. Insects that Feed on Trees and Shrubs. Cornell University Press, Ithaca, NY. 560 pp. $2^{\text {nd }}$ ed., rev.

Landis, D. A., S. D. Wratten, and G. M. Gurr. 2000. "Habitat Management to Conserve Natural Enemies of Arthropod Pests in Agriculture." Annual Review of Entomology 45:175-201.

Lonsdale, O., and S. J. Scheffer. 2011. "Revision of Nearctic Holly Leafminers in the Genus Phytomyza (Diptera: Agromyzidae), Including Descriptions of Four New Species." Annals of the Entomological Society of America 104 (6): 1183-1206. https://academic.oup.com/aesa/ article/104/6/1183/2758604

Martin, C. O., and S. P. Mott. 1997. Yaupon (Ilex vomitoria): Section 7.5.10, U.S. Army Corps of Engineers Wildlife Resources Management Manual. Vicksburg, Mississippi. Mead, F. W. 1983. Yaupon psyllid, Gyropsylla ilicis (Ashmead). Florida Department of Agriculture and Consumer Services, Division of Plant Industry, Entomology Circular No. 247:1-2. https://www.fdacs.gov/content/ download/10641/file/ent247.pdf 
Mead, F. W. 2014. Citrus flatid planthopper, Metcalfa

pruinosa (Say) (Insecta: Hemiptera: Flatidae). EENY-329.

Gainesville: University of Florida Institute of Food and

Agricultural Sciences. https://edis.ifas.ufl.edu/in605

Palumbo M. J., S. T. Talcott, and F. E. Putz. 2009. "Ilex vomitoria Ait (yaupon): A Native North American Source of a Caffeinated and Antioxidant-Rich Tea. Economic Botany 63 (2): 130-137. https://link.springer.com/article/10.1007/ s12231-009-9078-3

Qiao, G., J. Wang, and G. Zhang. 2008. “Toxoptera Koch (Hemiptera: Aphididae), a Generic Account, Description of a New Species from China, and Keys to Species." Zootaxa 1746:1-14.

Scheiber S. M., E. F. Gilman., D. R. Sandrock, M. Paz, C. Wiese, and M. M. Brennan. 2008. "Postestablishment Landscape Performance of Florida Native and Exotic Shrubs under Irrigated and Nonirrigated Conditions." HortTechnology 18 (1): 59-67. https://journals.ashs.org/ horttech/view/journals/horttech/18/1/article-p59.xml

Shadow R. A. 2011. "Plant Fact Sheet for Yaupon, Ilex vomitoria." USDA-Natural Resources Conservation Service, East Texas Plant Materials Center, Nacogdoches, TX, 75964. https://www.nrcs.usda.gov/Internet/FSE_PLANTMATERIALS/publications/etpmcfs10349.pdf

Spencer K. A., and G. C. Steyskal. 1986. Manual of the Agromyzidae (Diptera) of the United States. U.S. Department of Agriculture, Agriculture Handbook No. 638.

USDA, NRCS. 2019. The PLANTS Database: Ilex vomitoria Aiton. National Plant Data Team, Greensboro, NC 27401-4901 USA. https://plants.sc.egov.usda.gov/core/ profile? symbol=ILVO 